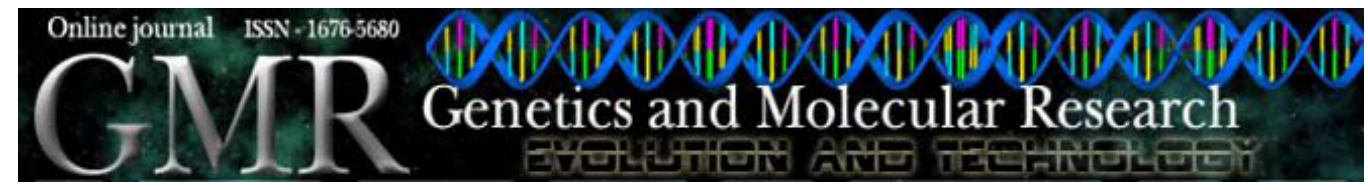

\title{
Estimates of genetic trend for carcass traits in a commercial broiler line
}

\author{
J.L.B.M. Grosso ${ }^{1}$, J.C.C. Balieiro ${ }^{1}$, J.P. Eler ${ }^{1}$, J.B.S. Ferraz ${ }^{1}$, \\ E.C. Mattos ${ }^{1}$, T. Michelan Filho², A.M. Felício ${ }^{3}$ and F.M. Rezende ${ }^{1}$ \\ ${ }^{1}$ Departamento de Ciências Básicas, Grupo de Melhoramento Animal \\ e Biotecnologia, Faculdade de Zootecnia e Engenharia de Alimentos, \\ Universidade de São Paulo, Pirassununga, SP, Brasil \\ ${ }^{2}$ Aviagen do Brasil Ltda., Rio Claro, SP, Brasil \\ ${ }^{3}$ Departamento de Zootecnia, Laboratório de Biotecnologia Animal, \\ Escola Superior de Agricultura Luiz de Queiroz, \\ Universidade de São Paulo, Piracicaba, SP, Brasil \\ Corresponding author: J.L.B.M. Grosso \\ E-mail: janelaragrosso@usp.br
}

Genet. Mol. Res. 8 (1): 97-104 (2009)

Received October 29, 2008

Accepted November 18, 2008

Published February 3, 2009

ABSTRACT. Data from the slaughter of 24,001 chickens that were
part of a selection program for the production of commercial broilers
were used to estimate genetic trend for absolute carcass (CW), breast
meat (BRW), and leg (LW) weights, and relative carcass (CY), breast
meat (BRY), and leg (LY) weights. The components of (co)variance and
breeding values of individuals were obtained by the restricted maximum
likelihood method applied to animal models. The relationship matrix
was composed of 132,442 birds. The models included as random effects,
maternal additive genetic and permanent environmental for CW, BRW,
LW, CY, and BRY, and only maternal permanent environmental for LY,
besides the direct additive genetic and residual effects, and as fixed ef-
fects, hatch week, parents' mating group and sex. The estimates of ge-
netic trend were obtained by average regression of breeding value on
generation, and the average genetic trend was estimated by regression
coefficients. The genetic trends for CW ( 6.0336 g/generation), BRW
( +3.6723 g/generation), LW ( +1.5846 g/generation), CY ( $+0.1195 \%$ / 
generation $)$, and BRY $(+0.1388 \%$ /generation $)$ were positive, and they were in accordance with the objectives of the selection program for these traits. The genetic trend for LY (-0.0019\%/generation) was negative, possibly due to the strong emphasis on selection for BRY and the negative correlations between these two traits.

Key words: Animal breeding; Breeding value; Carcass yield; Genetic gain; Poultry

\section{INTRODUCTION}

Over the last four decades, one of the greatest and most competitive agro-industrial complexes has been developing in Brazil: broiler production. From the beginning of this enterprise in the early 1970s up to now, nothing similar has been seen in the national agribusiness arena (Pinazza and Lauandos, 2000). Currently, the country is the third largest producer and the largest exporter of chicken meat in the world, with around 10.2 million tons produced and 3.3 million tons exported in 2007 (ABEF, 2008). The world production of chicken meat, according to the United States Department of Agriculture (USDA, 2007), registered an increase of $6.2 \%$ in 2007 from 64 million to 68 million tons, with Brazil accounting for $15 \%$ of global production. All this development, not only in the Brazilian broiler industry but also worldwide, is mainly due to the intense selection process carried out and the usage of crossbreeding among breeds, which has resulted in a change of traditional concepts, producing specific lines with particular characteristics.

In the poultry industry, market changes are very common, requiring continuous improvement in the scheme and tools of breeding programs (Yang et al., 1999). Consequently, it is necessary to conduct a detailed study of the needs of the food industry and an analysis of market trends, so that the targets of genetic progress are established (Figueiredo et al., 2000). According to Schmidt and Figueiredo (1996), the poultry industry, once again, will define the product to be produced based on the benefits that it will offer to the complete chain, from reproduction to post-slaughter processes. As a result of this entire process, the focus for the selection of commercial broiler lines, considering mainly the male lines (Lesson and Summers, 2000), has been much more intense for the carcass traits providing advances in terms of carcass and portion yield rate of the animals, as a consequence of a world trend of the largest consumption of chicken meat being in parts (Flemming et al., 1999), mainly breast meat (Pollock, 1997).

As in any animal breeding program, it is necessary to follow the results so that it is possible to evaluate their development, as well as to make effective adjustments, aimed at the optimization of genetic gain and increase in profitability of production. Thus, the study of genetic trend in a population is an important element in the monitoring of selection methods, since it corresponds to observed changes in the average breeding values of animals studied for a specific trait during the selection work. According to Costa et al. (2001), the study of genetic trend allows for the visualization of the efficiency of the selection procedures used and the quantification of the genetic changes of the traits under selection over time, besides the possibility of correcting eventual mistakes in the direction of selection (van Melis et al., 2001). According to Hudson and Kennedy (1985), the follow-up and the interpretation of genetic trend estimates allows monitoring the efficiency of improvement strategies and assures that 
the selection pressure is directed towards the traits of economic importance, besides assisting in the definition of the selection objectives.

In this manner, the estimation of genetic trend of absolute and relative weights of carcass traits in broilers selected in Brazil makes it possible to direct, lead and even evaluate the efficiency of the selection applied, comparing the objectives of selection work in breeding programs. Besides, there are very few studies of genetic trends in chickens described in the literature (Le Bihan-Durval et al., 1998; Costa et al., 2005; Rezende et al., 2005; Gaya et al., 2005b, 2007; Mourão et al., 2008; Vayego et al., 2008), which makes it even more important to measure these parameters.

Therefore, the objective of the present study was to estimate genetic trend for absolute and relative weights of carcass traits in a commercial broiler line by the regression of breeding values over seven generations of selection.

\section{MATERIAL AND METHODS}

\section{Data}

The information utilized came from siblings of an elite flock used for the production of commercial broilers belonging to Aviagen do Brasil. These individuals are part of a program denominated sib testing whose purpose is to evaluate carcass traits, helping to choose the best animals during the selection program of the elite flock. The chicks were placed in the company's broiler houses and raised with vaccination programs and nutritional management as recommended by Agroceres Ross (2004). At 6 weeks, from November 2002 to December 2006, each flock of chickens was transported to the Experimental Processing Plant of the University of São Paulo, Pirassununga, SP, Brazil (21 $\left.{ }^{\circ} 58^{\prime} \mathrm{S} ; 4^{\circ} 26^{\prime} \mathrm{W}\right)$. The chickens were on feed withdrawal for a minimum period of $10 \mathrm{~h}$ before slaughter. After slaughter, the carcasses were stored in a cold room at $0^{\circ} \mathrm{C}$ for $24 \mathrm{~h}$, for later processing into portions and deboned.

The information collected from the individuals included carcass weight $(\mathrm{CW})$, corresponding to the warm carcass weight, eviscerated, without neck, feet, abdominal fat, and internal organs; breast meat weight (BRW), where the breast was boneless and skinless, recorded after the carcass was refrigerated; leg weight (LW), corresponding to the thigh plus drumstick weight with skin and bones. The relative weights of carcass (CY), breast meat (BRY), and leg (LY) were calculated as the ratio between the absolute weights of each trait and the body weight at 6 weeks before slaughter. Approximately, 24,000 individuals were submitted for the collection of data for the carcass traits.

\section{Statistical analysis}

Data were processed at the Animal Breeding and Biotechnology Group, Department of Basic Sciences of the College of Animal Science and Food Engineering, University of São Paulo, Pirassununga, SP, Brazil (www.fzea.usp.br/gma). The extreme values defined as outliers were identified by the UNIVARIATE procedure of the SAS software (SAS Institute, 2004) and eliminated from the data set. The descriptive statistics (i.e., number of observations, mean, standard deviation, coefficient of variation, and minimum and maximum values) were calculated by the MEANS procedure of the SAS software (SAS Institute, 2004) and are illustrated in Table 1. 
Table 1. Number of observations (N), observed mean (Mean), standard deviation (SD), coefficient of variation $(\mathrm{CV})$, and minimum (Min.) and maximum (Max.) values of the traits evaluated.

\begin{tabular}{|c|c|c|c|c|c|c|}
\hline Trait & $\mathrm{N}$ & Mean & SD & CV (\%) & Min. & Max. \\
\hline $\mathrm{CW}$ & 24,001 & $1,934.22$ & 284.99 & 14.73 & 798.00 & $2,882.00$ \\
\hline BRW & 23,529 & 534.32 & 94.51 & 17.69 & 199.00 & 902.00 \\
\hline LW & 23,515 & 671.11 & 113.26 & 16.88 & 260.00 & $1,028.00$ \\
\hline $\mathrm{CY}$ & 24,001 & 70.56 & 1.85 & 2.62 & 62.23 & 78.62 \\
\hline BRY & 23,529 & 19.52 & 1.87 & 9.58 & 12.49 & 27.51 \\
\hline LY & 23,515 & 24.47 & 1.44 & 5.87 & 17.47 & 31.80 \\
\hline
\end{tabular}

$\overline{\mathrm{CW}}=$ absolute carcass weight $(\mathrm{g})$; BRW = absolute breast meat weight $(\mathrm{g})$; $\mathrm{LW}=$ absolute leg weight $(\mathrm{g}) ; \mathrm{CY}=$ relative carcass weight $(\%) ; \mathrm{BRY}=$ relative breast meat weight $(\%)$; LY = relative leg weight $(\%)$.

The components of (co)variance, used to estimate the coefficients of heritability to predict the breeding values of the individuals are illustrated in Table 2. These values were obtained by the restricted maximum likelihood method, using the MTDFREML software (Boldman et al., 1995). The relationship matrix was composed of 132,442 birds.

Table 2. Components of (co)variances and estimates of heritability coefficients with respective standard errors (SE) for absolute weights of carcass (CW), breast meat (BRW) and leg (LW), and relative weights of carcass (CY), breast meat (BRY) and leg (LY).

\begin{tabular}{|c|c|c|c|c|c|c|c|}
\hline \multirow[t]{2}{*}{ Trait } & \multicolumn{5}{|c|}{ Components } & \multicolumn{2}{|c|}{ Parameters } \\
\hline & $\hat{\sigma}_{a}^{2}$ & $\hat{\sigma}_{m}^{2}$ & $\hat{\sigma}_{a, m}$ & $\hat{\sigma}_{c}^{2}$ & $\hat{\sigma}_{e}^{2}$ & $\hat{h}_{\sigma}^{2}(\mathrm{SE})$ & $\hat{h}_{m}^{2}(\mathrm{SE})$ \\
\hline CW (g) & $4,351.78$ & 995.28 & $-1,786.20$ & $2,094.44$ & $19,710.68$ & $0.17(0.02)$ & $0.04(0.01)$ \\
\hline BRW (g) & 796.25 & 188.69 & -342.48 & 323.92 & $2,146.98$ & $0.26(0.03)$ & $0.06(0.01)$ \\
\hline LW (g) & 822.49 & 79.52 & -163.58 & 247.91 & $2,680.49$ & $0.22(0.02)$ & $0.02(0.01)$ \\
\hline CY (\%) & 0.61 & 0.03 & -0.06 & 0.05 & 1.27 & $0.32(0.03)$ & $0.02(0.01)$ \\
\hline BRY (\%) & 0.83 & 0.06 & -0.12 & 0.11 & 0.72 & $0.52(0.04)$ & $0.04(0.01)$ \\
\hline LY $(\%)$ & 0.42 & - & - & 0.02 & 0.55 & $0.43(0.03)$ & - \\
\hline
\end{tabular}

$\hat{\sigma}_{a}^{2}=$ direct additive genetic variance; $\hat{\sigma}_{m}^{2}=$ maternal additive genetic variance; $\hat{\sigma}_{a, m}=$ covariance between the direct and maternal additive genetic effects; $\hat{\sigma}_{c}^{2}=$ variation due to maternal permanent environmental effects; $\hat{\sigma}_{e}^{2}=$ variation due to residual effects; $\hat{h}_{\alpha}^{2}=$ coefficient of heritability for direct additive genetic effect; $\hat{h}_{m}^{2}=$ coefficient of heritability for the maternal additive genetic effect.

The animal models used in the univariate analysis included as random effects, maternal additive genetic and permanent environmental for CW, BRW, LW, CY, and BRY, and only maternal permanent environmental for LY, besides the direct additive genetic and residual effects. Such models are in accordance with the preliminary analysis that shows significant reduction on the estimate of $-2 \log \mathrm{L}$ (likelihood function), according to the likelihood ratio test (Dobson, 2002). In matrix notation, the most complete model can be presented as:

$$
\mathbf{y}=\mathbf{X b}+\mathbf{Z}_{1} \mathbf{a}+\mathbf{Z}_{2} \mathbf{m}+\mathbf{W c}+\mathbf{e},
$$

(Equation 1)

where $\mathbf{y}$ is the vector of observations; $\mathbf{b}$, the vector of fixed effects; $\mathbf{a}$, the vector of random direct additive genetic effect; $\mathbf{m}$, the vector of random maternal additive genetic effect; $\mathbf{c}$, the vector of random maternal permanent environmental effect; $\mathbf{e}$, the vector of random residual 
effect, and $\mathbf{X}, \mathbf{Z}_{1}, \mathbf{Z}_{2}$ and $\mathbf{W}$, the incidence matrices relating the observations to the fixed effects, random effects direct and maternal additive genetic, and maternal permanent environmental, respectively.

Considered fixed effects were the hatch week (104 levels), the parents' mating group (50 levels) and the sex of the birds (two levels), and they were the same for all models studied. The parents' mating group are the flocks from which the parents of each individual originated, representing the total environmental condition in which these flocks were submitted and that influenced the progenies' performance. The importance of these effects was determined by the GLM procedure of the SAS software (SAS Institute, 2004), which was significant $(\mathrm{P}<0.0001)$ for the traits studied.

The genetic trend for the carcass traits was estimated by regression of average breeding values of birds in seven generations of selection, according to the regression model:

$$
\mathbf{y}=\mathbf{a}+\mathbf{b x}+\mathbf{e},
$$

(Equation 2)

where $\mathbf{y}$ is the average breeding value; $\mathbf{x}$, the generation; $\mathbf{a}$, the equation constant; $\mathbf{b}$, the angle coefficient of the equation (linear regression coefficient), and $\mathbf{e}$, the random residual, NID ( 0 , $\left.\sigma^{2}\right)$. The average genetic trend was estimated by regression coefficients, whose importance were determined by the GLM procedure of the SAS software (SAS Institute, 2004), which was significant for all evaluated traits. The regression and determination coefficients were estimated by the REG procedure of the SAS software (SAS Institute, 2004), which made it possible to determine genetic development in this population for all traits studied.

\section{RESULTS AND DISCUSSION}

The genetic trend estimates for CW, BRW, and LW were positive, i.e., +6.0336 , +3.6723 , and $+1.5846 \mathrm{~g} /$ generation, respectively (Table 3; Figures $1 \mathrm{~A}-\mathrm{C}$ ), indicating that throughout the generations evaluated, these traits tend to increase in the population being studied. Rezende et al. (2005), working with an animal model including as random effects direct additive genetic and residual, and considering as regression the average of breeding values due to the years of selection, found trends of +2.70 and $+1.92 \mathrm{~g} / \mathrm{year}$ for $\mathrm{CW}$ and $\mathrm{LW}$, respectively.

\begin{tabular}{|c|c|c|c|}
\hline Trait & $b^{* * *}$ & SE & $\mathrm{R}^{2}$ \\
\hline $\mathrm{CW}$ & +6.0336 & 0.0472 & 0.1096 \\
\hline BRW & +3.6723 & 0.0204 & 0.1957 \\
\hline LW & +1.5846 & 0.0245 & 0.0307 \\
\hline CY & +0.1195 & 0.0007 & 0.1630 \\
\hline BRY & +0.1388 & 0.0008 & 0.1726 \\
\hline LY & $-0.0019 * *$ & 0.0007 & 0.0001 \\
\hline
\end{tabular}

$\mathrm{CW}=$ absolute carcass weight $(\mathrm{g}) ; \mathrm{BRW}=$ absolute breast meat weight $(\mathrm{g}) ; \mathrm{LW}=$ absolute leg weight $(\mathrm{g}) ; \mathrm{CY}=$ relative carcass weight $(\%)$; BRY $=$ relative breast meat weight $(\%)$; $\mathrm{LY}=$ relative leg weight $(\%) .{ }^{* * *} \mathrm{P}<0.001 ;{ }^{* *} \mathrm{P}<0.01$. 

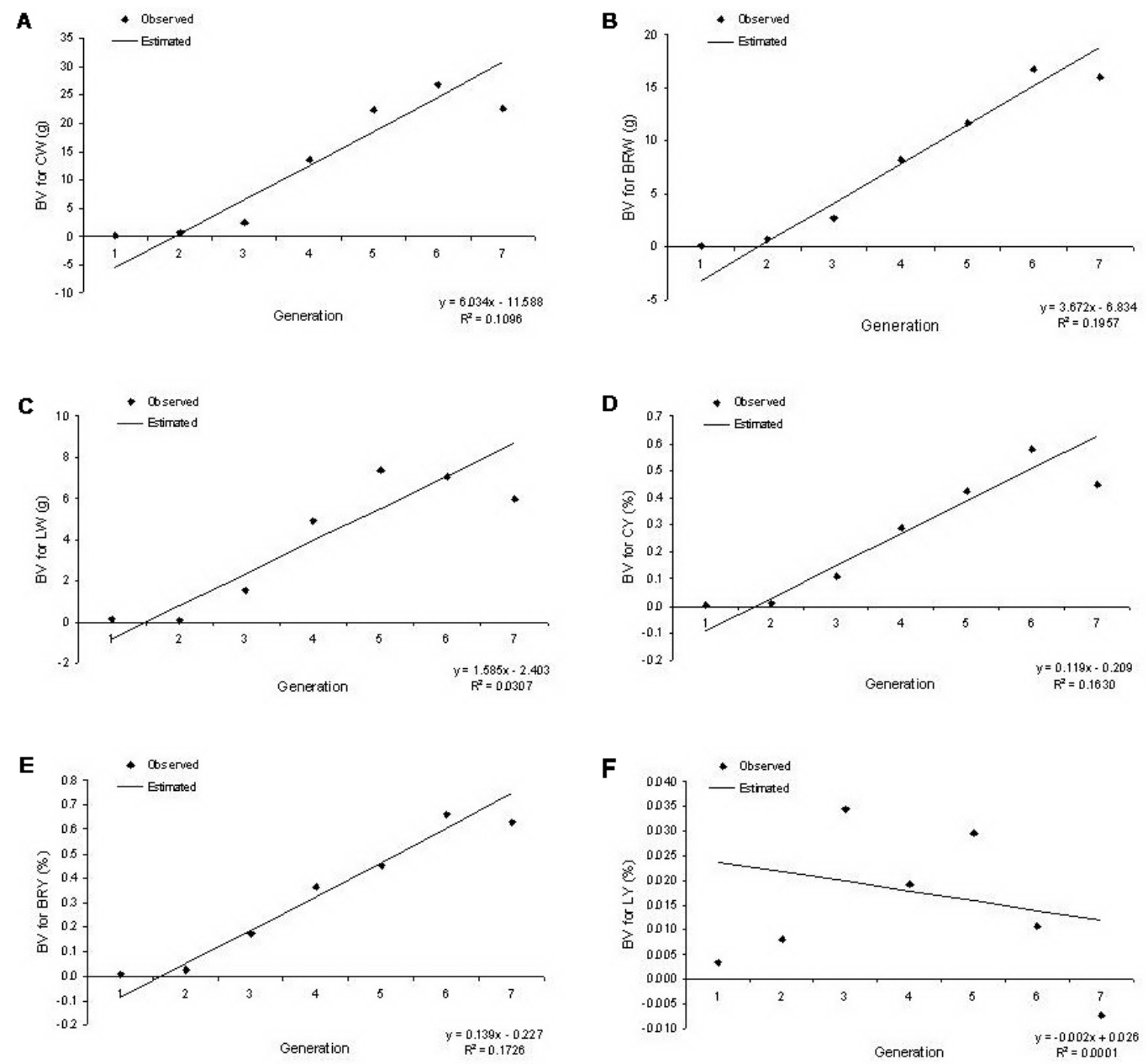

Figure 1. Genetic trends for A. absolute carcass weight (CW); B. absolute breast meat weight (BRW); C. absolute leg weight (LW); D. relative carcass weight (CY); E. relative breast meat weight (BRY), and F. relative leg weight (LY) over the generations studied estimated by regression analysis. BV = breeding values.

In a similar way, the genetic trend estimates obtained for CY and BRY were positive, i.e., +0.1195 and $+0.1388 \%$ /generation, respectively (Table 3; Figure 1D, E), agreeing with the objective of the present selection program, which is to increase the gain of these traits. The genetic trends for BRW and BRY were greater than the ones observed by Le Bihan-Durval et al. (1998) who reported values of $+2.786 \mathrm{~g} /$ generation and $+0.0975 \% /$ generation, respectively.

For LY, the genetic trend estimate was negative, i.e., $-0.0019 \% /$ generation (Table 3; Figure 1F), possibly due to the greater emphasis given to the selection of BRY and the negative correlations between these traits. Estimates of negative genetic correlation between BRY and LY (-0.74) were reported by Gaya et al. (2005a). 
According to the graphs, it can be seen that there is an increase in breeding values for all traits studied over the generations evaluated, except with LY. Smaller gains for LY occurred, possibly, due to the greater emphasis given to the selection of BRY, as it represents a big interest for the poultry industry, and the negative correlations between the two traits.

The results obtained in the present study indicate that the strategies of the adopted selection in the breeding program of the population in question, during the period of the study, seem to be efficient in promoting genetic progress in the carcass traits analyzed.

\section{ACKNOWLEDGMENTS}

Research supported by FAPESP (Fundação de Amparo à Pesquisa do Estado de São Paulo) and CNPq (Conselho Nacional de Desenvolvimento Científico e Tecnológico).

\section{REFERENCES}

ABEF (Associação Brasileira dos Produtores e Exportadores de Frangos) (2008). Relatório Anual 2007/2008. Available at [http://www.abef.com.br/]. Accessed August 5, 2008.

Agroceres Ross (Agroceres Ross Melhoramento Genético de Aves) (2004). Manual de Manejo de Frangos Agross. UmDesign, Campinas.

Boldman KG, Kriese LA, van Vleck LD, van Tassel CP, et al. (1995). A Manual for Use of MTDFREML: A Set of Programs to Obtain Estimates of Variances and Covariances (DRAFT). ARS-USDA, Lincoln.

Costa AMMA, Gaya LG, Mourão GB, Mattos EC, et al. (2005). Estimativas de Tendências Genéticas do Peso do Coração e do Peso do Fígado em uma Linhagem Macho de Frangos de Corte. In: Anais da Conferência APINCO de Ciência e Tecnologia Avícolas APINCO, Santos, 177.

Costa ARC, Lopes PS, Torres RA, Euclydes RF, et al. (2001). Tendências genéticas em características de desempenho de suínos das raças Large White, Landrace e Duroc. Rev. Bras. Zootec. 30: 348-359

Dobson AJ (2002). An Introduction to Generalized Linear Models. Chapman and Hall/CRC, Boca Raton.

Figueiredo EP, Schmidt GS, Rosa PS and Ledur MC (2000). O Programa de Melhoramento Genético de Aves da EMBRAPA. In: Anais do $3^{\circ}$ Simpósio Nacional de Melhoramento Animal, Belo Horizonte, 58-62.

Fleming JS, Janzen SA and Endo MA (1999). Rendimento de carcaça em linhagens comerciais de frangos de corte. Arch. Vet. Sci. 4: 61-63.

Gaya LG, Nakashima SH, Mourão GB and Mattos EC (2005a). Estimativas de Parâmetros Genéticos e Fenotípicos para Medidas de Ultra-sonografia de Músculo Peitoral e Características de Carcaça em Linhagem Macho de Frangos. In: Anais da 42ª Reunião Anual da Sociedade Brasileira de Zootecnia, Goiânia.

Gaya LG, Mourão GB, de Rezende FM, de Mattos EC, et al. (2005b). Genetic trends of abdominal fat content in a male broiler chicken line. Genet. Mol. Res. 4: 760-764.

Gaya LG, Costa AM, Ferraz JB, Rezende FM, et al. (2007). Genetic trends of absolute and relative heart weight in a male broiler line. Genet. Mol. Res. 6: 1091-1096.

Hudson GFS and Kennedy BW (1985). Genetic evaluation of swine for growth rate and backfat thickness. J. Anim. Sci. 61: 83-91.

Le Bihan-Duval E, Mignon-Grasteau S, Millet N and Beaumont C (1998). Genetic analysis of a selection experiment on increased body weight and breast muscle weight as well as on limited abdominal fat weight. Br. Poult. Sci. 39: 346-353.

Lesson S and Summers JD (2000). Broiler Breeder Production. University Books, Guelph.

Mourão GB, Gaya LG, Ferraz JB, Mattos EC, et al. (2008). Genetic trend estimates of meat quality traits in a male broiler line. Genet. Mol. Res. 7: 749-761.

Pinazza LA and Lauandos IP (2000). Voando a mil: da explosão da produção à competição acirrada das indústrias em um mercado saturado, o setor mostra suas asas. Agroanalysis 20: 12-17.

Pollock DL (1997). Maximizing yield. Poult. Sci. 76: 1131-1133.

Rezende FM, Gaya LG, Mourão GB, Mattos EC, et al. (2005). Estimativas de Tendências Genéticas do Peso Eviscerado e do Peso de Pernas em uma Linhagem Macho de Frango de Corte. In: Anais da Conferência APINCO de Ciência e Tecnologia Avícolas APINCO, Santos, 160.

SAS Institute (Statistical Analysis System Institute) (2004). User's Guide: Statistics. SAS Institute Inc., Cary.

Genetics and Molecular Research 8 (1): 97-104 (2009)

CFUNPEC-RP www.funpecrp.com.br 
Schmidt GS and Figueiredo EP (1996). Situação Atual e Perspectivas do Programa de Melhoramento Genético de Aves do CNPSA/EMBRAPA. In: Anais do $1^{\circ}$ Simpósio Nacional de Melhoramento Animal, Ribeirão Preto, 99-122.

USDA (United States Department of Agriculture) (2007). Relatório anual ABEF 2007/2008. Available at [http://www. abef.com.br/]. Accessed August 5, 2008.

van Melis MH, Eler JP and Ferraz JBS (2001). Tendências Genéticas para Características Produtivas e de Avaliação Visual em Bovinos da Raça Nelore. In: Anais da $38^{a}$ Reunião Anual da Sociedade Brasileira de Zootecnia, Piracicaba, 519-520.

Vayego SA, Dionello NJL and Figueiredo EAP (2008). Estimativas de parâmetros e tendências genéticas para algumas características de importância econômica em linhagem paterna de frangos de corte sob seleção. Rev. Bras. Zootec. 37: 1230-1235.

Yang A, Emmerson DA, Dunnington EA and Siegel PB (1999). Heterosis and developmental stability of body and organ weights at hatch for parental line broiler breeders and specific crosses among them. Poult. Sci. 78: 942-948. 